\title{
RADIOGRAPHICAL CHANGES IN THE ELBOW JOINTS OF CHAINSAW OPERATORS
}

\author{
Hiroshi UNE, ${ }^{*}$ Shinichi KoNDO** and Masanori Goto** \\ チェンソー使用伐木労働者の肘関節 $\mathrm{X}$ 線学的変化 \\ 畧博, 近 藤 真 一**, 五 島 正 規**
}

\begin{abstract}
The purpose of this study is to clarify the relation between the labor history of chainsaw operators and changes in their elbow joints. Osteophytic and degenerative changes on X-ray films of the elbow joints were compared quantitatively between chainsaw operators and a control group of age-matched road maintenance workers. Subjects were divided into three groups according to length of chainsaw use. Although no statistically significant differences were found among the three groups, radiographical examination showed significant changes $(p<0.05)$ in the subjects as compared with the controls.

Because of other labor factors that were not considered, the existence of a dose-response relationship between elbow damage and length of chainsaw use cannot be confirmed from this study, but such a relationship is suggested.
\end{abstract}

\section{INTRODUCTION}

It has often been pointed out from clinical observation that many chainsaw operators have had significant changes in their elbow joints compared with controls, ${ }^{1,2)}$ although one report, ${ }^{3)}$ showed no such difference. The purpose of this study is to determine whether chainsaw operators have more significant changes in their elbow joints than other manual workers, and whether there is a dose-response relationship between the changes in their elbow joints and the length of chainsaw use.

The changes in the elbow joints of chainsaw operators are mainly osteophytic and degenerative. ${ }^{1,2,4)}$ The degree of these changes gradually increases with age. ${ }^{5,6)}$ To prove whether labour factors cause these elbow joint changes, it is neces-

* Department of Hygiene, School of Medicine, Fukuoka University

** Shikoku Kinro Hospital

Received for publication, October 17, 1984

* 福岡大学医学部衛生学教室

** 四国勤学病院

昭和 59 年 10 月 17 日受付 sary to compare quantitatively the changes in the elbow joints of chainsaw operators with those of a control group, eliminating age as a confounding factor. In this study, these conditions were fulfilled by quantifying osteophytic and degenerative changes on X-ray films of the elbow joint, and matching age.

\section{MATERIALS AND METHODS}

1. Materials. Out of 507 chainsaw operators working in national forests in Kochi Prefecture in April, 1973, 375 underwent X-ray examination of the elbow joints in routine medical check-ups during 1973-77. As controls, 26 road maintenance workers in the central part of Kochi Prefecture had X-ray examination of the elbow joints during 1977-79.

The mean age, the mean length of chainsaw use, and the prevalence of Raynaud's Phenomenon in the 375 chainsaw operators were $45.3 \pm 7.4 \mathrm{yr}$ (mean $\pm S D$ ), $92 \pm 3.7 \mathrm{yr}$ (mean $\pm S D$ ), and $49.6 \%$ respectively. The mean age of the 26 road maintenance workers was $52.1 \pm 6.0 \mathrm{yr}$ (mean $\pm S D$ ). The road maintenance workers used bushcutters for a very short period of time during summer, but, none of 
them had symptoms such as Raynaud's Phenomenon or paresthesia of fingers, which are often observed in patients with vibration syndrome.

2. Methods. The left elbow joint was X-rayed from two directions to obtain a anteroposterior view in the extension position and a lateral view in a $90^{\circ}$ flexion position.

The findings were quantified in the following ways:

Eight sites, in which osteophytes are most likely to occur, ${ }^{4)}$ were examined (Fig. 1). When less than $2 \mathrm{~mm}$ of osteophyte was observed, one point was given. When more than $2 \mathrm{~mm}$ was observed, two points were given. Loose bodies in the joint scored three points. Likewise, for each of the articular surfaces of the humero-ulnar and the humero-radial joints, one point was given when sclerosis of the subchondral bone was observed, and two points when both sclerosis of the subchondral bone and narrowing of the joint space were identified. The degree of radiographical change was estimated from the total score.

Chainsaw operators were divided into three groups according to the length of chainsaw use: $7 \mathrm{yr}$ or less $(N=160), 8-12 \mathrm{yr}(N=115)$, and $13 \mathrm{yr}$ or more $(N=100)$. Age-stratified random sam-
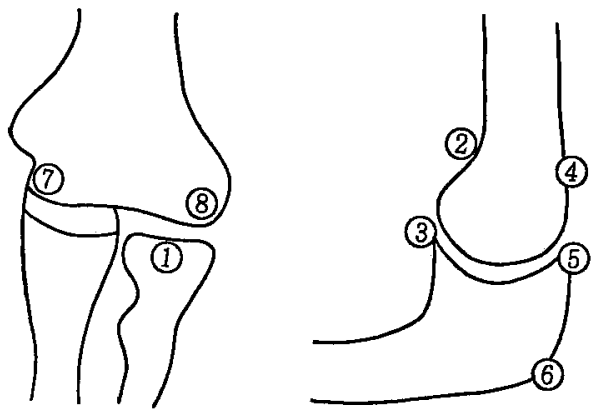

Fig. 1. Site of elbow joint. (1) radial head, (2) coronoid fossa, (3) coronoid process, (4) olecranon fossa, (5) tip of olecranon, (6) olecranon, (7) trochlea, (8) capitulum. plings were taken from the three groups at a ratio of $1: 1: 1$, and also from the 375 chainsaw operators and the 26 road maintenance workers at a ratio of $2: 1$.

The sampling procedure was as follows: for sampling from the three groups, first, an individual was randomly selected from among the 375 chainsaw operators and allocated to one of the three categories. In each of the other two categories, an individual was randomly selected from among the chainsaw operators age-matched $( \pm 2 \mathrm{yr})$ to the selected individual. This process was repeated and 66 pairs were selected from the three groups. The 26 road maintenance workers were agematched $( \pm 2 \mathrm{yr})$ to 52 subjects selected from the 375 chainsaw operators.

A chi-square test was used for statistical significance.

\section{RESULTS}

The mean age, the mean length of chainsaw use, and the prevalence of Raynaud's Phenomenon in 52 subjects randomly selected from the 375 chainsaw operators were $52.0 \pm 6.0 \mathrm{yr}$ (mean $\pm \mathrm{SD}$ ), $9.5 \pm 3.8 \mathrm{yr}$ (mean $\mathrm{SSD}$ ) and $57.7 \%$ respectively. These statistics are shown in Table 1.

Figure 2 shows typical X-ray films of an elbow joint with a score of 4; Fig. 3 shows examples of one with a score of 11 .

Table 2 shows distributions of the total scores for the 52 chainsaw operators and the 26 road maintenance workers. The level of changes observed in the elbow joints of chainsaw operators were significantly $(p<0.05)$ higher than those of road maintenance workers.

With radiographical changes quantified, a comparative study was carried out to detect any differences among the three groups. Table 3 shows distributions of the scores. The averages of the scores in the three groups were 2.23 for $7 \mathrm{yr}$ or less, 2.82 for $8-12 \mathrm{yr}$, and 3.2 for $13 \mathrm{yr}$ or more.

Table 1. Mean age, mean length of chainsaw use and prevalence of Raynaud's Phenomenon in three groups divided on the basis of length of chainsaw use.

\begin{tabular}{lccc}
\hline Three groups & $\begin{array}{c}\text { Mean age } \\
(\mathrm{yr})\end{array}$ & $\begin{array}{c}\text { Mean length of use } \\
\text { of chinsaws }(\mathrm{yr})\end{array}$ & $\begin{array}{c}\text { Prevalence of Raynaud's } \\
\text { Phenomenon }\end{array}$ \\
\hline 7 yr or less $(N=66)$ & $46.1 \pm 6.3$ & $5.3 \pm 1.7$ & $20 \%$ \\
$8-12$ yr $(N=66)$ & $46.1 \pm 6.4$ & $10.5 \pm 1.5$ & $46 \%$ \\
13 yr or more $(N=66)$ & $46.1 \pm 6.3$ & $13.7 \pm 0.8$ & $47 \%$ \\
\hline
\end{tabular}


Table 2. Comparison of radiographical changes in the elbow joints between chainsaw operators and road maintenance workers.

\begin{tabular}{lcccccccccccccccccc}
\hline & \multicolumn{11}{c}{ Degree of radiographical changes (total score) } \\
\cline { 2 - 13 } & 0 & 1 & 2 & 3 & 4 & 5 & 6 & 7 & 8 & 9 & 10 & 11 & 12 & 13 & 14 & 15 & 16 \\
\hline $\begin{array}{c}\text { Road maintenance workers } \\
(N=26)\end{array}$ & 10 & 6 & 3 & 2 & 3 & 1 & 0 & 0 & 0 & 0 & 0 & 0 & 0 & 1 & 0 & 0 & 0 \\
$\begin{array}{c}\text { Chainsaw operators } \\
(N=52)\end{array}$ & 2 & 13 & 11 & 9 & 2 & 2 & 0 & 2 & 3 & 2 & 0 & 3 & 2 & 0 & 0 & 0 & 1 \\
\hline
\end{tabular}

Total score: see the text. Chi-square was calculated from a $2 \times 3$ table with total scores for the degree of radiographical changes aggregated into three groups: 0 to 1,2 to 4 , and 5 or more. This table yielded a chi-square of 8.94 with 2 degrees of freedom $(p<0.05)$.

Table 3. Radiographical changes in the elbow joints in three groups divided on the basis of length of chainsaw use.

\begin{tabular}{|c|c|c|c|c|c|c|c|c|c|c|c|c|c|c|c|}
\hline \multirow{2}{*}{ Three groups } & \multicolumn{15}{|c|}{ Degree of radiographical changes (total score) } \\
\hline & 0 & 1 & 2 & 3 & 4 & 5 & 6 & 7 & 8 & 9 & 10 & 11 & 12 & 13 & 14 \\
\hline $\begin{array}{c}7 \mathrm{yr} \text { or less } \\
(N=66)\end{array}$ & 15 & 19 & 12 & 8 & 2 & 3 & 1 & 1 & 1 & 4 & $\mathbf{0}$ & 0 & 0 & 0 & 0 \\
\hline $\begin{array}{l}8-12 \mathrm{yr} \\
\quad(N=66)\end{array}$ & 18 & 15 & 8 & 8 & 3 & 3 & 1 & 3 & 0 & 2 & 0 & 2 & 2 & 1 & 0 \\
\hline $\begin{array}{c}13 \text { yr or more } \\
(N=66)\end{array}$ & 10 & 14 & 14 & 9 & 5 & 2 & 2 & 1 & 2 & 2 & 0 & 3 & 1 & 0 & 1 \\
\hline
\end{tabular}

Total score: see the text. Chi-square was calculated from a $3 \times 3$ table with total scores for the degrees of radiographical changes aggregated into three groups: 0 to 1,2 to 4 , and 5 or more. The difference in radiographical changes between these three groups was not statistically significant at the $5 \%$ level (Chi-square= 4.67 with 4 degrees of freedom).

This result shows a tendency for radiographical changes to become more pronounced with longer chainsaw use, but the differences were not statistically significant.

\section{DISCUSSION}

Shinomiya et al..$^{1)}$ and Matoba et al. ${ }^{2)}$ reported from clinical observation that many chainsaw operators show significant changes on X-ray films of their elbow joints. Their findings were mainly non-specific osteophytic and degenerative changes. Although a strong association is observed between osteophytic and degenerative changes and aging, no study of the quantitative relation between changes in the elbow joints of chainsaw operators and their labour has been able to eliminate age as a confounding factor.

Age, labour, and nutrition are the major factors causing osteophytic and degenerative changes. ${ }^{5-8)}$ Therefore, labour or nutritional factors appear to cause the difference in the changes of the elbow joints between chainsaw operators and road maintenance workers in this age-matched study.

As exact data on their nutritional conditions were not available, it is unknown whether nutritional factors are associated with the differences found in this study. However, little difference exists in wage levels between these two groups because both are made up of manual workers employed by the government. If nutrition is a factor at all, it is most likely a minor one.

On the other hand, in regard to labour factors, Futatsuka ${ }^{10)}$ reported higher vibration acceleration levels in chainsaws than in bushcutters. Chainsaw operators use chainsaws all year round, while road maintenance workers use bushcutters only for a very short period in summer. This may explain why the prevalence of Raynaud's Phenomenon among the 52 chainsaw operators was $57.7 \%$, and that of the 26 road maintenance workers was nil. It is clear that chainsaw operators are exposed to 


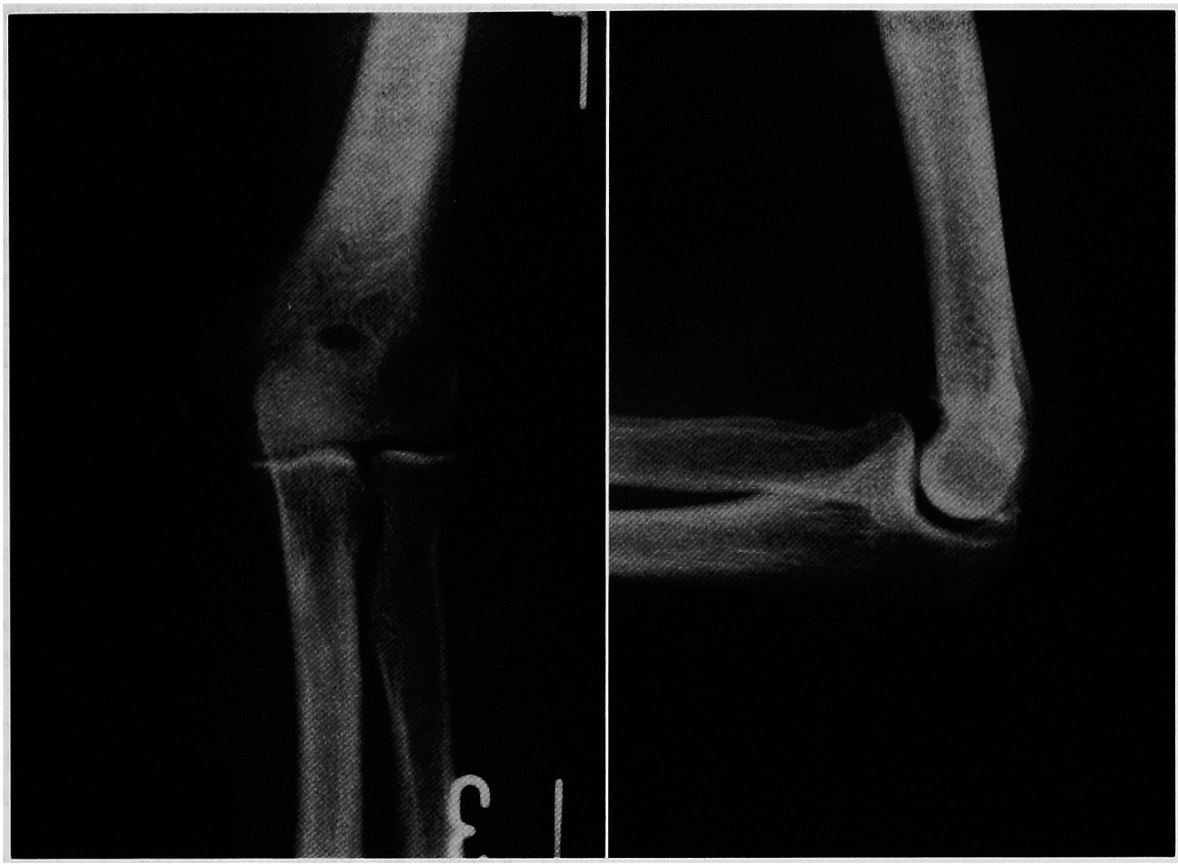

Fig. 2. Example of X-ray films of an elbow joint with a total score of 4 .

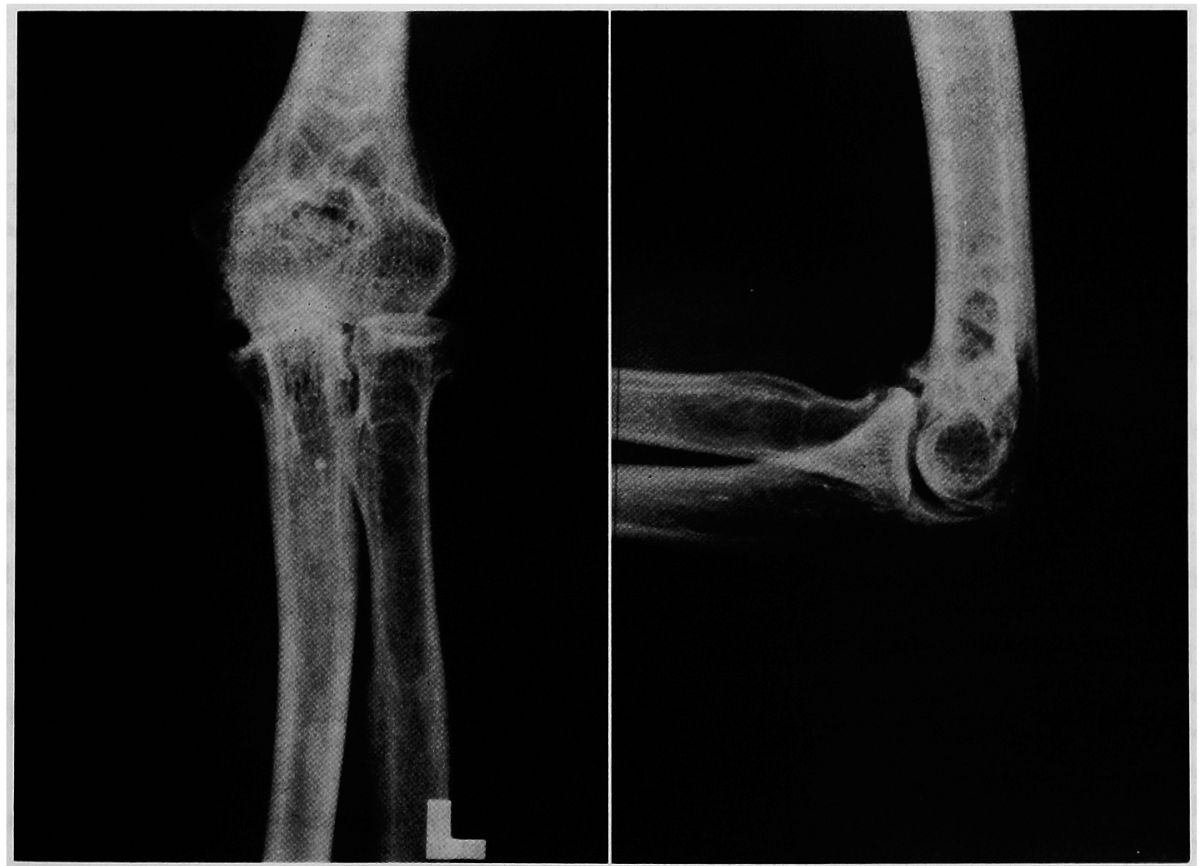

Fig. 3. Example of X-ray films of an elbow joint with a total score of 11 . 
far more vibration than road maintenance workers.

Aegerter and Kirkpatrick ${ }^{9)}$ find a higher incidence, an earlier onset, and a greater joint damage in workers who use their joints excessively than in those who do not. In other words, heavy use of the elbow joint can be harmful.

Chainsaw operators have to support heavy chainsaws with their arms while at work and also stretch and flex their arms repeatedly when using chainsaws and axes. Moreover, all 52 chainsaw operators used hand saws and axes to fell trees before they started using chainsaws. Although handsaws and axes do not involve vibration, workers using these tools must stretch and flex their arms repeatedly. Generally speaking, this is not the case with tools used by road maintenance workers.

Therefore the authors consider that the type of labour is the major factor causing the difference in radiographical changes between chainsaw operators and road maintenance workers. However, it remains to bedetermined whether it is the continuous flexing of the elbow joint or the vibration which is the primary cause of the damage.

As for the relation between the length of chainsaw use and radiographical changes, no statistically significant difference was observed among the three groups of chainsaw operators. However, there was a tendency for radiographical changes ot be more pronounced with longer use of chainsaws. In interpreting this finding, it should be taken into account that chainsaw operators were engaged in very heavy work $^{11}{ }^{12}$ ) before they began to use chainsaws. Before 1959, when the forest office in Kochi Prefecture introduced chainsaws. Only hand saws and axes were used to fell trees.

The years during which chainsaw operators actually used hand saws and axes were 3.1 \pm 5.0 (mean $\pm \mathrm{SD}$ ) for the group of $7 \mathrm{yr}$ or less, $8.0 \pm 7.2$ (mean \pm SD) for that of $8-12 \mathrm{yr}$, and $7.7 \pm 6.9$ (mean $\pm \mathrm{SD}$ ) for that of $13 \mathrm{yr}$ or more. Although little difference exists between the group of 8-12 $\mathrm{yr}$ and that of $13 \mathrm{yr}$ or more, the group of $7 \mathrm{yr}$ or less had had relatively little experience in using hand saws and axes. This is because many chainsaw operators belonging to the group of $7 \mathrm{yr}$ or less had been engaged in other types of work than felling trees, such as afforestation and lumber collecting.

Thus, as the authors cannot control labour factors other than chainsaw use, it cannot be positively concluded that there is a dose-response relationship between the length of chainsaw use and radiographical changes in the elbow joints. However, this result suggests the possibility of such a relationship.

Even if the authors assume the existence of a dose-response relationship, we cannot determine to what extent it results from vibration, and to what extent from simply holding and manipulating such a heavy device as a chainsaw.

\section{REFERENCES}

1) Shinomiya, F., Nishiyama, M. and Sugita, J.: Osteoarthritis of the elbow joint and cubital tunnel syndrome in patients with vibration syndrome and its treatment, Jpn. J. Traumatol. Occup. Med., 29: 449-456, 1981.

2) Matoba, T., Kusumoto, H., Kuwahara, H., Inanaga, K., Oshima, M., Takamatsu, M. and Esaki, K.: Pathophysiology of vibration disease, Jpn. J. Ind. Health, 17: 11-18, 1975.

3) Kimura, M., Egawa, T. and Doi, T.: Local vibration disturbance of wood-cutters, Sumitomo Bull. Ind. Health, 3: 140-151, 1967.

4) Une, H.: A study on vibration disorder among chain saw operators-Effect of leaving off chainsaw operation on recovery of disorder, Okayama Igakkai Zasshi, 92: 943-958, 1980.

5) Turek, S.L.: Orthopedics, Principles and Their Application (4th ed.), 384-401, J.B. Lippincott Company, Philadelphia, 1984.

6) Goodfellow, J.W. and Bullough, P.G.: The pattern of ageing of the articular cartilage of the elbow joint, J. Bone J. Surg., 49B: 175-181, 1967.

7) Kellgren, J.H.: Osteoarthosis in patients and populations, Br. Med. J., 2: 1-6, 1961.

8) Mintz, G. and Fraga, A.: Severe osteoarthritis of the elbow in foundry workers, Arch. Environ. Health, 27: 78-80, 1973.

9) Aegerter, E. and Kirkpatrick, J.A.: Orthopedic Disease (3rd ed.), 742-749, W.B. Saunders Company, Philadelphia, 1968.

10) Futatsuka, M.: A study on the vibration hazards due to using bush cutters, Jpn. J. Ind. Health, 21: 269-273, 1979.

11) Sekiguchi, Y. and Uchida, T.: On the energy metabolism of feller, J. Sci. Labour, 27: 471-476, 1951.

12) Kusunoki, T.: Change of forest labor accompanied by its mechanization, J. Sci. Labour, 33: 322-331, 1957. 


\section{和 文 要 旨}

チェンソーを使用している代木労働者に高度の时関節 の変化を有する者が多いことが報告されている，そこ で, 彼らの时関節の变化と学伍要因との関連を明らかに する目的て，肘関節 X線上の骨增殖性变化を定量化し， confounding factor としての年龄を matching して, control group (道路工手) と比較検討した。 また，同様 にして，伐木学働者をチェンソー使用経験年数別に 3 段 階に分類して比較し，チェンソー使用量による时関節へ の影竡を湌討した。
その結果, チェンソー使用伐木労䣦者の肘関節 $\mathrm{X}$ 線学 的変化は control group (道路工手) と比較して有意に 高度であった。 また，伐木学働者をチェンソー使用経験 年数別㐳分類して比較した結果, 差は有意でなかった がチェンソー使用経験年数が長くなるにしたがい，肘 関節X線学的変化は高度になる傾向が認められた. しか し，キェンソー使用経験年数別に分けた 3 群の間炕は ェンソーの使用を開始する以前の学傎内容に若千の違い があるため, チェンソ一使用量と肘関節X線学的变化の 間に直ちに dose-response relationship があると結論す ることはできないが，本研究の結果はその可能性を示唆 するものであると考えられる.

Reprint requests to Department of Hygiene, School of Medicine, Fukuoka University, 7-45-1, Nanakuma, Jonan-ku, Fukuoka City, 814-01 Japan (H. Une) 著者への通信先 : 畧 博, T81401 福岡市城南区七隈 7-45-1 福岡大学医学部衛生学教室 